\title{
Culture, Politics and Contested Identity among the "Kurdish" Alevis of Dersim: The Case of the Munzur Culture and Nature Festival
}

\author{
Ülker Sözen ${ }^{1}$ \\ Netherlands Institute in Turkey
}

\begin{abstract}
This article analyzes the Munzur Culture and Nature Festival organized by the people of Dersim, an eastern province of Turkey, as a site of political activism, cultural reproduction, and intra-group contestation. The festival began as a groupremaking event for restoring cultural identity, defending locality, and mobilizing Dersimli people in the face of political repression. In time, socio-spatial and political fragmentation within Dersimli society became more prevalent. The festival experience came to reflect and contribute to the debates and anxieties about identity whereby different political groups competed to increase their influence over local politics as well as the event itself. On the one hand, this article discusses the organization of the Munzur Festival, its historical trajectory, and the accompanying public debates and criticisms. On the other, it explores festive sociabilities, cultural performances, and the circulation of politically-charged symbols throughout the event which showcases the articulation and competition of multiple ethno-political belongings which are the Dersimli, Kurdish, Alevi, and socialist ones. The festival's historical trajectory is dealt as two stages, unified struggle and internal strife, whereby the festival appeared as first a group-remaking then unmaking public event. The paper argues that this transformation is tied to hanging power relations in the local politics of Dersim, and the shifting state policies, namely the phase of repressive control strategies until the mid-2000s and the peace process and political relaxation until 2015.
\end{abstract}

\section{Introduction}

The Munzur Culture and Nature Festival has been taking place since 2000 in Dersim/ Tunceli ${ }^{2}$, a province located in Eastern Anatolia with a population predominantly composed of Alevis ${ }^{3}$ whose native tongues are Zaza language (Zazaki) and Kurdish for the most part. The festival is an annual event happening for four days in late July and early August. Hometown associations of Dersimli people who migrated to western parts of Turkey and local political actors in the city, which are the Kurdish movement and left-wing groups, have been the organizers of the event.

My first time as a researcher in the Munzur Festival was during the summer of 2012. It was arguably the heyday of "the peace process"4 between the Turkish government and the Kurdish movement. Due to cease fire and relaxation of control measures in the city, the touristic allure of Dersim was rampant owing to its socially liberal environment and natural beauty, and the festival would attract many Kurdish visitors from adjacent cities, who mostly belonged to the Shafii sect of Sunni Islam. This would engender tensions in the city arising from the contested character of Dersimli identity and its discordant relationship with the Kurdish movement (Faltis, 2014).

One morning during the 2012 festival, I was travelling with a shuttle bus for attending the festivities in Hozat, a district of Dersim. I started chatting with the shuttle driver and his assistant. The day before, I had heard about an altercation in a touristic campsite at the shores of the Munzur River, where some visitors and city folk, especially young people would lodge during the festival time to enjoy the nature and the convivial social ambiance. There was a confrontation between Dersimliler and Mardinliler ${ }^{5}$ while allegedly a man from Mardin had sexually harassed a woman. The incident culminated in a fight among the camp dwellers who had banded along the lines of their hometowns. When I asked about this incident, the driver's

\footnotetext{
${ }^{1}$ Corresponding: E-mail: ulk.sozen@gmail.com

${ }^{2}$ The province had been named Dersim in the mid $-19^{\text {th }}$ century by Ottoman authorities with reference to a powerful tribe confederation called Desiman inhabiting the region (Y1ldırım, 2013). That name was officially changed to Tunceli, meaning "the land of bronze" in 1935 by the Turkish Republic as a part of its efforts to solidify state authority in the province and Turkify its people. In contemporary Turkey, the official name of the province is still Tunceli and one of the major goals of Dersimli identity politics is to officially bring back the original name of the province.

${ }^{3}$ Though there are various interpretations of Alevism, the broadest definition would be that it is a heterodox and syncretic religious conviction following the Twelve Imams tradition of Shia Islam.

${ }^{4}$ Peace talks between the Turkish government and the Kurdish armed insurgent organization, PKK began after 2005 in Europe, which is publicly known as the "Oslo process". The government accompanied the negotiations, although not officially acknowledging them, with a series of democratizing reforms addressing Kurdish cultural and political rights (Cavanaugh and Hughes 2015). The peace process collapsed in the summer of 2015 after the general elections in June. Then, the Turkish state launched a crackdown against the pro-Kurdish political institutions and activists that intensified after the declaration of the state of emergency law following the military coup attempt against in the summer of 2016.

${ }^{5}$ This means "people from Mardin". Mardin is a province located in the South-Eastern Turkey whose population is multi-ethnic including Sunni Arabs and Syriac people and the majority is composed of Kurdish people endorsing Shafii Islam.
} 
assistant, a Dersimli man in his early twenties told me "Our brothers coming out of the city are our guests. But some of them are not familiar with our ways here. They get drunk and cause trouble". He was clearly bothered by the harassment but cautious in not stereotyping and antagonizing the Kurdish festival visitors. As he used the term "brothers" as a token of affinity, I felt that he did not want to acclaim the widespread discourse in the city emphasizing Dersimli people's inherent incompatibility and cultural boundaries with Kurds.

In my following exchanges with the Dersimli people, I encountered many narratives flagging up this ambivalent perception of commonality and difference with Kurds, and many others fervently defending that Dersimli people are not Kurdish. Furthermore, I noticed that the festival experience, in addition to enacting the contentious activism of Dersimli people for claiming place and identity, revealed their internal disputes and anxieties stemming from deep-seated cultural matters and contemporary socio-political transformations.

This article seeks to discuss the Munzur Festival as a site of political activism, cultural expression, and internal public debate. On the one hand, it examines the festival's production regarding the stakeholder actors, their negotiations and conflicts, and the shifting power configurations. On the other, it explores festive sociabilities, performances, and symbolisms which display political activism and reflect the multiple collective belongings that shape the experience of being Dersimli. Underlying these foci, the paper holds that the Munzur Festival transpired as an arena of "performative reflexivity" whereby identity and politics are negotiated in relation to the evolution of Dersimli society and the changing political circumstances in Turkey within the last two decades.

Cultural performances such as rituals and festivals are not only expressions of specific cultures and their ideals, they also function as mediums of public address and social change (Conquergood, 1991, p. 188). Victor Turner used the term "performative reflexivity" to explain this aspect as follows:

Performative reflexivity is a condition in which a sociocultural group, or its most perceptive members acting representatively, turn, bend or reflect back upon themselves, upon the relations, actions, symbols, meanings, codes, roles, statuses, social structures, ethical and legal roles, and other sociocultural components which make up their public 'selves" (Turner, 1988, p. 24).

Deriving from this definition, I view the Munzur Festival as a field of cultural and political performances leading Dersimli people to reflect on their collective identity, political attachments, the meanings attributed to locality, and the legitimate ways of relating to the natural and symbolic landscape of Dersim. Furthermore, the event itself contributed to the ways in which the concerns and sensibilities of Dersimlis have changed over the last two decades. Without doubt, the political actors wishing to influence and orient Dersimli society towards their convictions, manipulated the festival performances for promoting their agendas or in the cases where they could not manage to shape the festival, used it as an outlet for addressing social disturbances and calling for change.

\section{Methodology}

This research is part of my dissertation project investigating the cultural politics of identity and memory among Dersimli society whose field study was conducted between the spring of 2012 and the summer of 2017. It deploys an analysis of public discourses and festive sociability regarding the Munzur Festival which is arguably the most prominent stage of the cultural productions and discourses about collective identity and memory launched by Dersimli society. I used triangulation for data collection whereby I conducted in-depth interviews and ethnographic research, and analyzed published material.

I did twenty-four interviews specifically on the organization and public reception of the Munzur Festival with people including festival organizers, frequent festival performers and participants, and representatives of political groups in the city. I reviewed the commentaries and news items about the Munzur Festival published in printed and online media. In addition to those publications of political groups, I focused on media channels and popular social media accounts appealing to Dersimli public, the Kurdish movement, and left-wing movements. Furthermore, I attended the festivals between 2012 and 2017 and carried out ethnographic research by observing festival activities.

"[P] eople construct identities (however multiple and changing) by locating themselves or being located within a repertoire of emplotted stories" argues Margaret Somers. That is, people give meaning to their experiences "on the basis of the projections, expectations, and memories derived from a multiplicity but ultimately limited repertoire of available social, public, and cultural narratives" (Somers, 1994, p. 614). Moreover, temporal, spatial, and relational aspects of this constitution should be considered in order to make sense of narrativity. Following these insights, in the individual and public discourses that I collected, I tried to uncover the prominent narratives about collective identity, locality, and memory while putting them in historical and socio-political context.

My involvement in the field and my interpretations regarding the topic have been affected by my subjective position as a non-Dersimli person of Turkish Sunni origins. I experienced some level of difficulty in getting accepted in the field wherein ethnic and political identities matter a lot which posed a limitation. For instance, I was not accepted to any of the festivals' organization meetings held at the Tunceli 
municipality. Almost all my exchanges were with Dersimli individuals resulting in the lack of the perspectives of non-Dersimli people reflected in this study which is a delimitation. Besides, I specifically focused on those people who engage actively with the festival as organizers, performers, and/ or public commentators rather than the common festival goers which might be another delimitation.

\section{Ethno-Religious Complexity and Socio-Political Fragmentation in Dersim}

Following the popularization of identity and memory politics among Dersimli people in the 1990s in the form of an identitarian revival, researchers began to examine the subject matter. They point out the multi-faceted and contested character of Dersimli identity oscillating between Kurdish, Alevi and socialist belongings, and contentions over collective memory (Bruinessen, 1997; Dinç, 2018; Gezik, 2012; Leezenberg, 2003; Sözen, 2016; Törne, 2015). As Dersimli people mobilized to claim their cultural identity and challenged nation-state politics, they simultaneously engaged in heated debates about how to define themselves and their historical origins; prioritizing their native tongue, culture or belief system as markers of identity, whether as Kurds, Zazas, Alevis, acculturated Armenians or an ethnic group by themselves separate from the rest.

The cultural politics and narratives produced by Dersimli society provide a rich ground for addressing the interplay of diverse parties within a marginalized ethnic group in the pursuit of reclaiming their identity. In addition to political multiplicity, there is the socio-spatial fragmentation of Dersimli society whereby the majority of Dersimli population migrated to western Turkish cities and European countries while retaining links to their hometown. This complicates the concerns and conflicts with regards to the experience and expressions of Dersimli identity. Hence, this article seeks to provide an analysis of the dynamic and contested constitution of identity and addresses the question of how political and socio-spatial differentiations shape a counter-hegemonic field of cultural politics.

In order to make sense of Dersimli people's cultural politics and the Munzur Festival, their history of antagonism with the state, multifaceted identity, and socio-political differentiations should be explained. It is argued that Dersim had emerged as an organizational and spiritual center for Anatolian Alevis, who had been suppressed by the Ottoman Empire, since the $17^{\text {th }}$ century owing to its mountainous landscape obstructing the military campaigns of the Ottomans (Gezik, 2012, p. 65). The Dersim province hosted Zazaki, Kurdish, and Turkish-speaking Alevi tribes in addition to a Turkish Sunni minority and Armenian Christians in the late Ottoman era, whereas the latter group had been gradually eradicated and converted to Alevism throughout the early $20^{\text {th }}$ century. Beginning with the mid-19 ${ }^{\text {th }}$ century, the Ottoman Empire initiated modernization and centralization reforms which culminated in a series of military campaigns for overthrowing the semi-autonomous rule of Dersimli tribes. The Turkish Republic continued this endeavor in the 1920s while also trying to suppress the ethnic awareness and secessionist movement among Kurds taking root in the province (Bruinessen, 1994, p. 153).

The Turkish Parliament issued a legislation specific to Dersim in 1935, officially changed its name to Tunceli, and declared military state of emergency rule. Some tribes reacted to the state's growing interventions with attacks over government posts. Regarding those as a full-fledged insurgency, the Republic waged a massive military campaign over Dersim with the use of warplanes, heavy artillery, and chemical weapons during the years 1937 and 1938. The toll of the 1937-38 military campaign were nearly thirteen thousand deaths according to official records, while Dersimli commentators estimate up to seventy thousands of casualties including both armed tribesmen and civilians (Ayata and Hakyemez, 2013, p. 135). Besides the mass killings, the state forcefully resettled more than ten thousand Dersimlis to the western parts of the country as a measure to scatter the tribal authorities in the region. The leader of resistance Seyit Riza, a powerful tribal chief, and his companions were executed in 1937. In the following decades, Seyit Riza has been sanctified as a heroic martyr figure and collective symbol of identification for Dersimli people and the Kurdish movement.

The atrocity of 1937-38 created an immense trauma pertaining to feelings of loss and uprootedness among Dersimli people whose collective memory was transferred through oral history across generations. It is widely claimed that the trauma of 1937-38 is the foundational collective experience for the Dersimli identity (Gürtaş, 2015, p. 321). Beginning with the 1990s, this trauma was publicized and entered into wider circulation through oral history research, literary and musical productions, and documentaries initiated by Dersimli people.

Dersimli people have participated in the socialist left for almost six decades and lent support to counter-hegemonic politics extensively. During the rise of the left in Turkey in the 1960s, Dersimli youth tended to join revolutionary organizations while some of them involved with the left-wing branches of Kurdish nationalist movement (Bruinessen, 1997, p. 14). The TKP/ML ${ }^{6}$, a Maoist organization upholding rural guerilla warfare, turned out to be the most influential socialist group in Dersimli society to the degree

\footnotetext{
${ }^{6}$ Türkiye Komünist Partisi/ Marksist Leninist [The Communist Party of Turkey/ Marxist-Leninist]
} 
of becoming an almost-organic component of their politico-cultural collective belonging. Even after the 1980 coup when the left-wing opposition was forcefully crushed, Dersim remained the last stronghold for the TKP-ML. Supporters of this organization is chiefly composed of Dersimli people to the extent that this group is known as Tunceliler [people from Tunceli] in leftist circles (Leezenberg, 2003, p. 199). Demokratik Haklar Federasyonu (DHF) ${ }^{7}$, the strongest of the TKP/ML's descendant political organizations, is one of the most influential political actors in contemporary Dersimli society possessing significant electoral power. The candidate supported by the DHF, competing against the candidate of pro-Kurdish party, received nearly a third of the votes in the 2009 municipal elections in Tunceli. Moreover, some district municipalities of the city, the most renowned being Ovacik, were won by the affiliates of the organization in 2009 and 2014 local elections.

In addition to socialist organizations, Dersimli people have actively participated in the Kurdish movement led by the $\mathrm{PKK}^{8}$ since the 1980s. There were several Dersimli individuals among the initial cadres of the PKK which was formed as an illegal political party in 1978. The PKK embraced separatist left-wing nationalism and the use of military struggle as the primary means for achieving independence until the 2000s when the movement began advocating for radical democracy and confederal governance (Akkaya and Jongerden, 2011, p. 153). The organization commenced insurrection in Kurdish-populated cities in the mid-1980s and rapidly developed a solid support base in the region. However, the PKK's relationship with Dersimli people proved to be troublesome. It did not have a strong foothold in the province initially because of the existence of other socialist guerrilla groups sustained by Dersimli folk (Leezenberg, 2003, p. 205).

The PKK rose to prominence in Dersim as the main insurgent group in the 1990s. Meanwhile, it engaged in mortal conflicts with other guerilla groups and executed several uncooperative villagers. Some Dersimli critics, who happen to be the vocal actors of Dersimli identity revival, remind these events in their cases against the Kurdish movement and accuse the latter of imposing hegemony through violence in the region. Despite this tension, the Kurdish movement had expanded its support in the city since the mid-2000s by establishing a power block bolstered by some of the socialist groups not including the DHF. Regarding the municipal and general elections in the last decade, the pro-Kurdish party emerged as the dominant political power in the Dersim locale, but it could not establish hegemony while its politics are subject to various criticisms and challenges.

The counter-hegemonic politicization of Dersimli people was met with state repression since the 1970s. Martial law was declared in the city in 1979. After the 1980 coup, thousands of Dersimli people affiliated with socialist and Kurdish political organizations migrated to European countries as political refugees. The martial law in Dersim was changed to the state of emergency law $(O H A L)^{9}$ in 1986 which was finally abolished in 2002 until its declaration once again in 2016 after the coup attempt. During the mid-1990s, the state sanctioned severe military operations and control strategies in Dersim as well as other Kurdish provinces against the PKK insurgency. Those entailed village evacuations and burnings, foodstuff embargos, and blockades accompanied by extra-judicial killings and tortures. According to a report prepared by the Turkish parliament members, during the mid-1990s nearly 41 thousand villagers from the province were forced to resettle (Hacaloğlu et al., 1996, p. 12). The military operations and $O H A L$ enforcements deeply scarred the Dersimli people by destroying "not only their homes and economic means of subsistence, but also what was left of their traditional social fabric and cultural traditions" (Leezenberg, 2003, p. 207).

Consequently, Dersim's population fell dramatically from 158 thousand in 1980 to nearly 85 thousand since the mid-2000s, while the migrants moved to western Turkish cities and European countries, chiefly to Germany. This wave of mass migration created a significant socio-spatial fragmentation among Dersimli population differentiating the experience of and meanings attached to being Dersimli, accentuating the feelings of uprootedness, longing, and nostalgia as important components of collective identity for the migrants. Overall, the mid-1990s, which witnessed military operations and forced displacement, is registered to Dersimli collective memory similar to the destructive 1937-38 experience so that this era is commonly dubbed as "the second 38" in public and political discourses of Dersimli people.

Migrant Dersimli people, especially the diaspora in Europe, became pioneers in developing identity and memory politics whilst supporting their relatives in Dersim and seeking to become effective in local politics. They established hometown associations and organized for cultural reproduction and political representation during the late 1980s both in European and Turkish cities (Akçınar and Zırh, 2013). Although the Kurdish movement and socialist groups have been influential in these organizations since their onset, there emerged a separate identity consciousness among Dersimli people. The diaspora in Europe incited by the growing grip of identity politics, focused on their distinct ethno-cultural identity and began to define

\footnotetext{
${ }^{7}$ As part of the Turkish government's crackdown campaign following the coup attempt in the summer of 2016, the DHF was shut down by a statuary decree on the grounds of its alleged support for terrorism. The organization re-opened in 2017 under the name Sosyalist Meclisler Federasyonu.

${ }^{8}$ Partiya Karkeren Kürdistan [Kurdish Workers Party]

${ }^{9}$ Olağanüstü Hal
} 
themselves as Dersimli rather than Kurd and/ or Alevi (Sözen, 2013). They produced journals and other publications on vernacular Zazaki, Dersim's belief system, and the 1937-38 Massacre. This transnational identity revival resonated among the Dersimli people in Turkey engendering an interest in ethnic roots and oral history, despite adverse political conditions such as restrictions over the use of mother tongues other than Turkish.

As Martin van Bruinessen observed in the mid-1990s, "[a]mong no other group in Turkey is there such an intensive and self-conscious search for the most appropriate way to define oneself" (1997, p. 19). Dersimli public is intensely preoccupied with the question of ethnic origins, whether they are originally Kurds, Zazas, Alevis, a distinct ethno-cultural group labeled as Kırmanc ${ }^{10}$, and/or converted Armenians most recently ${ }^{11}$. This renders the Dersimli public an arena of competing identity projects. While the Kurdish movement is a powerful agent in this competition, the linguistic and religio-cultural specificities of Dersimli folk turn out to be troublesome points of dissonance. The majority of Kurds in Turkey speak the Kurmanci dialect of Kurdish while the prevalent mother tongue of Dersimli Alevis is Zazaki which is termed Kirmancki by the locals. There are intense debates within Dersimli and Kurdish publics whether Zazaki/ Kirmancki is a dialect of Kurdish or a separate language, which reflects the contested character of Dersimli identity. This controversy boils down to the questions whether Dersimli people are ethnically Kurds or Zazas and whether the Kurdish movement aims to assimilate Dersimli people by claiming that it is a subbranch of Kurdish in a similar fashion with the Turkish state.

The religious specificity of Dersimli people proves to be a more strained matter. Differing from the majority of Turkey's Kurdish population whose religious conviction is the Shafii sect of Sunni Islam, known for its strict orthodoxy, the faith of Dersimli people is Alevism which is commonly disfavored by Sunni religious authorities because of its perceived heresy and licentious ways. Correspondingly, there is a tenacious belief among some Dersimli people, especially the elder generation that Sunni Kurds are unreliable and hostile towards Alevis no matter what their political convictions are. This view has also been promoted by some pro-Kemalist ${ }^{12}$ Alevi intellectuals since the 1990 s.

\section{Inception of the Munzur Festival and Political Activism}

The Munzur Festival was initiated by the hometown associations established by Dersimli people, for the most part the one located in Istanbul which was founded in 1990. Hometown associations, Dersimli intellectuals, business people, artists, and thepolitical parties and groups influential in the city held a series of meetings during the mid-1990s for confronting the $O H A L$ enforcements in Tunceli, mainly village evacuations and burnings which resulted in a huge wave of depopulation. As a result, they formed an assembly uniting various parties called Dersim Dayanışma Kurulu ${ }^{13}$ through which they carried out lobbying activities for pleading with government members and mobilizing European politicians and human rights activists (Taş, 2007). Furthermore, they introduced several projects for providing economic, humanitarian, legal, and socio-economic assistance to the people in Dersim afflicted by the OHAL enforcements.

One of their projects was to organize a festival in the city with the purpose of revitalizing the city's economic and cultural life stricken by repressive control measures and military operations. In this regard, the early years of the Munzur Festival may be characterized with self-mobilization and political activism for claiming Dersimli identity and its locality as both a natural-ecological and symbolic landscape. One of the frequently-emphasized issues was law enforcement forces imposing strict control over the flow of food supplies to the villages with the concern that those were given to the armed militants of the PKK and other insurgent groups. The other was the control and restrictions imposed over migrant Dersimli individuals who wanted to visit the city and their villages on the grounds that they would have collaborated with the insurgent groups. Countering these security measures that isolated the province, Dersim Dayanışma Kurulu aimed at reversing depopulation and encouraging resettlement to Dersim, or at least motivating the tens of thousands Dersimli people scattered to Turkish and European cities to visit their hometown. And hence, the assembly organized a campaign in the summer of 1998 inviting migrant Dersimli people to spend their summer holiday in the city. However, this holiday program was met with backlash from the Tunceli governorate and the visitors who deemed to be "suspicious" were not allowed into the city.

The other initial motivation for the festival project was confronting the dam projects in the province. The state initiated several dam projects on the rivers of Dersim including the much-venerated Munzur river during the mid-1990s which have still being constructed to this day and whose numbers are increasing. Dersimli people began protesting the dam and hydroelectric power plant projects in their

\footnotetext{
${ }^{10}$ The groups who emphasized the term Klrmanc as the name of collective identity tend to defend that Dersimli people are a separate ethnic group by themselves.

${ }^{11}$ For the revival of Dersimli Armenian identity, see Tosun (2015).

${ }^{12}$ Kemalism refers to the political conviction following Mustafa Kemal Atatürk's political vision and secularist Turkish nationalism

${ }^{13}$ Dersim Solidarity Assembly.
} 
hometown and established several platforms for this cause weaving a strong anti-dam movement. Dersimli people tend to regard the dam projects as an appendage of the lingering _even centuries-old according to some evoking the bad blood with the Ottoman Empire_state ploy for displacing its people and depopulating Dersim (Orhan, 2013, p. 264).

"Return to your land, stake your claim to Munzur" and "Munzur will flow free" have become popular festival slogans since its early years, articulating the pursuit of freedom for both the river and the Dersimli people identifying with it. Public rallies were organized almost each year as part of the festival program after the abolishment of OHAL, with the attendance a couple of thousands for protesting the dams and showcasing the Dersimli people's strong espousal of the cause of protecting Munzur.

The Munzur river is sacred according to the traditional belief system of Dersimli people. There are several holy places called jiyara in its vicinity where people pray, light candles, and give sacrifices, which would bury under water in case of the dams. Along with this faith-based concern, there is a prominent ecological awareness which has been expressed in anti-dam rhetoric and petitions produced by Dersimli activists since their protests against village and forest area burnings in the mid-1990s. As part of their antidam struggle, Dersimli activist frequently emphasize the detrimental consequences of the dams on local wildlife and fauna, especially in the Munzur valley that hosts a unique ecosystem and was established as a national park in 1971. Moreover, supporters of the armed insurgent organizations interpret the construction of dams as a state strategy for preventing guerrilla activity in the region by disconnecting the mountainous areas through dam lakes.

The early festivals until the second half of the 2000s took place in a contentious political climate when the state sought to exert control over the event. In this context, the Munzur Festival came to prominence as a site of political struggle. The first festival was planned to be organized in 1999. The organizing committee collaborated with the Tunceli municipality then governed by the social democrat $\mathrm{CHP}^{14}$, and applied for the permission of the Tunceli governorate that is the local representative of the state. Just a short while before the planned festival time, the application was rejected for security reasons on the grounds that members of the organizing committee had untenable political affiliations. The following year, the festival was held in a celebratory environment and thirty thousand people, predominantly composed of migrant Dersimlis, poured in the city. The number of visitors rose each year as the popularity of the event grew. One of my respondents, a member of the initial organizing committee, recalled the sense of collective excitement and victory in the first festival of 2000 as: "Davul and zurna 15 were being played. People were hugging each other; crying and laughing at the same time. We were so happy, as if we made a revolution".

The Tunceli governorate had continued interventions in the festival program during the initial years in accordance with the state's restrictive policies in Kurdish-populated cities. Each year, representatives of the organizing committee held meetings with the governorate about the festival program. Though the organizing committee was composed of the deputies of hometown associations and of the pro-Kurdish and socialist political groups in the city, the representatives who carried out the negotiations with the governorate were individuals who were not overtly-political and openly-tied to the "suspicious" organizations. The governorate would seek to suspend the musicians and panelists whom the state viewed to be promoters of terrorism and Kurdish separatism, and demanded their replacement with pro-state writers and artists. The organizing committee negotiated for keeping the festival content in resonance with the demands of Dersimli public and the agendas of political organizations.

The festivals of 2001, 2004 and 2005 witnessed collective protests and clashes with state forces. In 2001 , in addition to the firm interventions to the festival program by the governorate, the visitors were subjected to several police controls within the city. On top of that, many Turkish flags were hung in the city center by the governorate and a banner in the stadium expressing gratitude to the leader of the ultranationalist political party $\mathrm{MHP}^{16}$ who was the deputy prime minister of Turkey at the time. This bravado of Turkish nationalism stirred up unrest among the Dersimli folk. Consequently, an outrage broke during the stadium event resulting in a serious altercation with police forces. For suppressing the protests, hundreds of soldiers and policemen marched in the city center chanting the nationalist slogan "all for the country".

In 2004, the intervention of police forces to the demonstration of a socialist group turned into a city-wide scuffle in which several protesters were critically injured. In 2005, the governorate issued a verdict for postponing the festival after a military operation against the Maoist militants in the province and the kidnapping of a travelling Turkish soldier by the PKK. Despite the deferral decision, the festival was held on time whereby festival activities were organized in non-official venues such as cafes and make-shift stages established at the shore of the Munzur river instead of the city stadium. The 2005 festival was celebrated as the victory of Dersimli people's determination to continue their reclamation of identity and locality vis-àvis the state.

\footnotetext{
${ }^{14}$ Cumhuriyet Halk Partisi [Republican People's Party]

${ }^{15}$ Drums and shrill pipe

${ }^{16}$ Milliyetçi Hareket Partisi
} 
My interviews revealed that the early festivals were thought to reflect collective feelings of empowerment and reclamation by Dersimli people. Various respondents with differing political affiliations expressed a common nostalgic longing for the initial years whereby senses of solidarity, mutual trust, and collective pride were reminisced. In a time when the use of mother tongues other than Turkish was suppressed, the public deployment of Kirmancki and Kurdish by the musicians during the festival concerts was an important source of collective pride as well as an act of cultural reclamation and defiance against Turkish nationalism. In this respect, one of my respondents, an organizing committee member from the Dersimli hometown associations, recounted how much joy and amusement he had felt during one particular instance in one of the earliest festivals. He told me how the governor and high-ranking military officers in the ceremonial VIP seats left the stadium frustrated after hearing the local musician began to sing in Kirmancki on stage during the opening ceremony of the festival.

Another accentuated point was that the spirit of the early festivals overcame the political and sociospatial differentiation among Dersimli people. In this respect, the theme of homecoming which indicates the embracement of diasporic Dersimlis by their fellow townsmen was emphasized in the nostalgic narratives about the early festivals. By this means, the point that festival visitors used to be hosted in the homes of local Dersimlis instead of hotels is underlined in both my interviews and the public discourses about the festival. Usually, these narratives of past congeniality are juxtaposed to the criticism of commercialization and anonymity in contemporary festivals.

Regarding political demarcations, it is argued that the Munzur Festival embodied Dersimli people's collective struggle surpassing the conflicts and competition between the Kurdish movement and the socialist organizations. That is, political repression united rivaling groups while they contained their disagreements for the common benefit of Dersimli society, which included protesting against the dam projects and state pressures, and the expression of the oppressed Dersimli identity. In this regard, in my interviews the early festival organizers from different movements mentioned how political groups did not push for thrusting themselves to the forefront, and acted in solidarity for the common cause of Dersimli people. In parallel with the theme of embracement between local and diasporic Dersimlis, the narratives about the unified struggle of past festivals also contain a comparison with contemporary festivals which are deemed to divisive and corrupted due to tiring political rivalry.

\section{Festival Politics and Internal Contestations}

Festivals are political formations deployed for a variety of purposes by political authorities (from above) and at the grassroots level (from below), and they may manifest as group-making, remaking, and unmaking events in the course of time (Leal, 2015, p. 594). That is, the festival experience may work for inducing feelings of unity and group mobilization (group-making), reviving the eroding cultural traditions and sense of identity (remaking), and witnessing or contributing to the disintegration of communal unity (unmaking). Dersimli people recall the mid-2000s as a turning point in both a positive and negative light with respect to the historical trajectory of the Munzur Festival as well as the socio-political life of Dersim. Protests regarding the organization and content of the event became more prevalent from then on which arguably transforms the festival from a group-remaking event to an unmaking experience.

Two factors account for this change, one at the local level and the other at the national. At the local level, the municipal election was won by the candidate of the Kurdish movement-led political alliance in 2004 for the first time, beating the CHP candidate. Proponents of the Kurdish movement view the CHP as a statist party which seeks to erase the essential Kurdishness of Dersimli people. Regarding the municipal and parliamentary elections since the early 2000s, the support for the CHP in Dersim entails a voting percentage ranging from twenty five to fifty rendering the party the main electoral opponent in the city for the Kurdish movement. However, considering the Munzur Festival officially organized by the Dersimli hometown associations and the Tunceli municipality, the CHP had been a fairly ineffective actor during its years in power in the city.

The pro-Kurdish party was elected for the consequent two terms in 2009 and 2014 which increased the Kurdish movement's influence in local politics, although not rendering it the sole hegemonic power. Supporters of the Kurdish movement celebrate this change of local governance and argue that the festival had finally begun to be organized by the rightful representatives of Dersimli folk. Whereas, the advocates of Dersimli identity politics, who consider the Kurdish movement as an assimilatory political force, emphatically suggested that the Munzur Festival ceased to be the festival of Dersimli people after 2004 and began to be ruled from Diyarbakir, the symbolic headquarter of the Kurdish movement.

The other factor at the national level accounting for the festival's transformation was the state's changing stance with regards to the Kurdish issue. The AKP government signaled the Kurdish opening project in 2005 and initiated peace negotiations with the armed section of the Kurdish movement, the PKK, although never officially acknowledged. Accompanying the negotiations, the government promised a policy shift entailing "de-securitization" of the Kurdish issue and the introduction of democratic reforms giving way to the political and cultural expressions of Kurdish identity (Cavanaugh and Hughes 2015, p. 17). This policy shift enabled the relaxation of security controls and political pressures in the eastern cities of Turkey 
including Dersim. It also provided grounds for the advancement of festivals and other cultural spectacles initiated by the Kurdish movement in Kurdish-populated cities. The deployment of cultural politics within a multiculturalist framework since the early 2000s has become a consequential strategy of the Kurdish movement for obtaining recognition (Scalbert-Yücel, 2016, p. 82-86).

Paralleling this, the AKP government had promoted a multiculturalist discourse and rhetorical retribution about the past injustices towards the Kurdish population, until the collapse of the peace process in the summer of 2015 after the general elections in June. Tayyip Erdoğan, as the then-prime minister, even uttered a semi-apology speech about the 1938 Massacre in 2011 in an official party meeting, which put the sole blame on the CHP, as the founding party of the Turkish Republic, rather than the state itself for this atrocity (Ayata and Hakyemez, 2013).

In such a context, the unequivocal state repression during the early festivals which once united the divergent political orientations within the Dersimli public gradually disappeared during the peace process. As the Kurdish movement extended its power in Dersim as well as nation-wide, it transpired as the dominant but not hegemonic actor in local politics. The pro-Kurdish party gained political power while running the Tunceli municipality and winning the parliament member seats for the city in general elections. It increased its influence in the prominent institutions of local politics and socio-economic life such as labor and trade unions. Nonetheless, the Kurdish movement was widely criticized and challenged in Dersim while a significant fragment of Dersimli people lend contextual support to it.

Dissident Dersimlis voiced complaints about the movement's alleged Kurdification agenda assimilating the separate ethno-cultural identity of Dersim and domineering attitude vis-à-vis other political groups. By this means, the Munzur Festival came to mirror internal differentiation and political contestations to a larger extent. Public criticisms and anxieties transpired centering on the conflicts regarding festival's organization, the content repeating itself over the years, environmental pollution and infrastructural problems during the festival time, and the opinion that the festival corrupting the idealized Dersimli values. Exemplifying this criticisms, a Dersimli man interviewed in the DHF's newspaper regarding the festival in the summer of 2011 said:

As it happened every year, the organization committee is undergoing conflicts during the planning. Cliquism and self-imposing mentality should be denounced. In this region, what is required is a common consciousness and spirit for reviving our social identity, countering the environmental destruction, and fencing off assimilation ${ }^{17}$.

Since its early years, the Munzur Festival was organized by two committees; one established in Istanbul by the Dersimli hometown associations and the other one in Dersim led by the municipality and involving local political and civil society organizations. The Kurdish movement via the Tunceli municipality became one of the two leading organizers of the festival after 2004. The other stakeholder is the DEDEF ${ }^{18}$, the umbrella organization of the Dersimli hometown associations in Turkish cities, which was founded in 2004. After the heightened competition between the DHF and the Kurdish movement in the 2009 local elections, the Kurdish movement sympathizers parted ways with the DEDEF and the DHF supporters gained superiority in the federation. Although other less-influential socialist groups exist in the festival's organization, the Kurdish movement which governed the municipality and the DHF through its influence over hometown associations emerged as the chief decisive actors in the festival's organization.

Complaints about the festival mostly pertained to the prolonged discussions and debates in the course of the preparation of the festival program. Negotiations in the committee meetings revolve around decisions about panel topics, panelists, and musicians. Many Dersimli individuals, whom I interviewed, regardless of their differing political affiliations, expressed a common weariness about the behavior of political groups. Accordingly, they seek their own agendas at the expense of the overall advancement of the event and push for featuring in the festival program the intellectuals and musicians associated with their movements. This pattern was viewed to be self-seeking and divisive, and cause the festival content to be repetitive over the years. Yet, it is ironic that even though adversary parties agreed on the source of the problem, no collective solution for the betterment of the festival that satisfies them could be produced.

Another prominent criticism was that the Munzur Festival failed to reflect the actual problems and concerns of Dersimli people. In this respect, the critics hold that the belief system and cultural identity of Dersimli people, which had already been damaged by state repression and mass migration, were again downplayed in the festival content. They claimed that Kurdish identity and the Kurdish movement's political agenda were given plenty of coverage. In addition, it was argued that the Kirmancki/ Zazaki language of Dersimli people was not used adequately and the Kurdish language dominated the festival program. In this respect, some Dersimlis even defend that the festival operated as an assimilatory tool by the Kurdish movement for Kurdifying Dersimli people.

\footnotetext{
17 "Festivale ilişkin görüşler", Halkın Günlüğü Festival Eki, July 2011, p. 3. Accessed in 04 May 2019 , https://issuu.com/solyayin/docs/hg_ozel_sayi_dersim_2011. Translation is mine.

${ }^{18}$ Dersim Dernekleri Federasyonu
} 
This critique is mostly voiced by the promoters of Dersimli identity politics who accuse both the Kurdish movement and the socialist organizations of corrupting the essence of Dersimli culture, manipulating it for their political interests, and detracting the Dersimli people from their authentic identity. This group, although not organized as a separate institutionalized political group, materialize their influence over the Dersimli public through certain hometown associations in Europe, mainly their umbrella organization Föderation der Dersim Gemeinden in Europa, and various media channels such as online news portals. It should be noted that this perspective is stronger among the Dersimli diaspora in European countries. The increasing number of non-Alevi Kurdish festival visitors during the peace process, which was linked to the encouragement of the pro-Kurdish municipality, was also interpreted as a trenchant source of disturbance by this party. The non-Alevi Kurdish festival visitors caused discomfort and anxiety for a considerable fragment of local Dersimlis with regards to the disruption of cultural homogeneity in their hometown.

In addition to the protests emanating from identity concerns, the socialist groups, especially the DHF as the most prominent one, raised criticisms towards the Kurdish movement. Accordingly, the Kurdish movement patronized other political groups and sought to decrease their role in the festival's organization. Members of the DEDEF, claiming to be the representative of the large migrant Dersimli population in Turkey and the original initiator of the festival, expressed resentment in this respect as well. A common complaint among the DHF affiliates was that the Munzur Festival turned into an entertainment-oriented, consumerist, and depoliticized spectacle during the peace process. That is, the festival which was incepted as a medium for anti-capitalist political activism degenerated into a vehicle for the commodification of culture and natural environment via tourism. Expansion of touristic infrastructure along the Munzur valley, which contributed to the degradation and pollution of the natural environment, was interpreted to be a direct outcome of the festival and hence condemned by the socialists.

The DHF-Kurdish movement divide in the festival's organization was sought to be resolved through a divergence within the festival's spatial organization. Beginning with the 2005 festival, the DEDEF and the DHF began to organize sub-branches of the Munzur Festival in the districts like Ovac1k and Mazgirt where they governed the municipalities, while leaving the decisive role in the festival's organization in the city center to the Kurdish movement.

\section{Performances, Symbols, and Sociabilities}

Social movements require collective performances and symbols energizing and exciting the masses, and sustaining collective effervescence, a sense of solidarity and moral density (Strunc, 2019; Tolba, 2018). Collins calls this communicable feeling "high ritual density" and names its ingredients as physical assembly of people, a shared focus of attention enabled through a common stereotyped action such as chanting, and the focus of attention becoming a mutual focus of attention while the group reaches a shared sense of awareness, incorporating moral and cognitive unison. The byproducts of such public rituals are feelings of solidarity, emotional energy, symbols of group codifying the collective memory of participation, and feelings of morality (Collins, 2001, p. 28). In this light, the Munzur Festival provided an affective site for the reproduction of belongings to the Dersimli, Kurdish, and socialist publics. Festive sociabilities, collective performances, and the circulation of culturally-relevant symbols throughout the event mediated the reinforcement and contestation of these ethno-political belongings.

Considering the festivals I observed during the peace process, the festival time brought a large influx of visitors and an energized, vibrant, fair-like social life to Dersim contrasting with the silent days of the city during the rest of the year. Political groups and their symbols were conspicuously visible in the cityscape during the festivals. The booths of various left-wing political groups were established in the city center displaying their publications and pamphlets. These political booths functioned for self-promotion and propaganda. Moreover, they served as gathering sites for supporters of the various socialist organizations and Kurdish movement, whereby they would exchange local gossip as well as ideas about everyday politics. I recall how I felt startled by the lengthy tension of a discussion during the 2013 festival between a municipality officer supporting the Kurdish movement and a publisher working on Dersimli culture. The municipality officer was trying to prove that she grasped with her knowledge of Kurdish, the children's book written in Kirmancki that the publisher sold. Whereas, the latter pointed out her mistakes as she read the book. This debate over linguistics exemplified one of the critical issues dividing the Dersimli public in the last thirty years indicating the contested Kurdishness of Dersimli people.

In addition to the political booths, many market stalls were established in the city center during the festival time catering the tens of thousands festival visitors. They sold traditional street food, the most popular being patila, a local pastry, and various memorabilia and trinkets such as lighters, bracelets, $t$-shirts, and pictures. Make-shift tattoo parlors attracted young festival visitors, who wanted to ornament their bodies with permanent or temporary inkings of Alevi, Dersimli, and socialist symbols. That is, even the commercial stalls of the Munzur Festival were not devoid of politics. The festival time souvenirs stood out with their symbolically-charged political imagery. 
It is possible to recount some of the most visible images displayed on the trinkets as follows: Hammer and sickle as the international symbol of Marxist struggle; zulfikar, the double-edged sword of Ali which is a major religious symbol for the Alevi faith; stylized depictions of Hasan and Hüseyin who were the martyred sons of Ali representing the eternal mourning of Alevi people ; the word Dersim and the number 62 which is the province code of Tunceli, kesk $u$ sor u zer meaning the Kurdish national colors of red, yellow, and green; and the Seyit Riza, Ibrahim Kaypakkaya ${ }^{19}$, and Che Guevera portraits conveying the vernacularized Dersimli socialist identity. The trinkets, posters, and other public images circulating during the festival time mediated the multi-faceted symbolism of the oppositional political public of Dersim articulating the Alevi, Kurdish, socialist, and Dersimli histories. These ethno-political belongings could go side by side at times and integrate with each other in festival-time symbols. Nonetheless, their circulation would also reflect the tensions within Dersimli society and its boundaries with the Kurdish movement. For instance, in the 2014 festival I recall how an elderly Dersimli woman living in Dă̆ Mahallesi, a relatively poor neighborhood of the city, expressed her dislike for the young men wearing t-shirts that have the word Kurdistan on them and some others dressed in stylized şal $u$ şapik, which is promoted by the Kurdish movement as traditional clothing. She told me that she had found them weird and unfitting to Dersim.

The stadium events in the festival time were another site where cultural and political symbolisms came to the forefront such as party flags and the portraits of the martyred youth leaders of the socialist organizations. The concerts which were held in the city stadium were the most crowd-pulling events of the festival. Especially the closing ceremony and concerts in the last day would become the pinnacle of the event. Political groups would attend the concerts with their flags and banners, chanting their slogans when the musicians and bands affiliated with their groups take the stage. During the 2013 festival's closing ceremony at the city stadium, I was mingling with my DHF-sympathizer acquaintances who were assigned to be stage security. The tension between the municipality's security staff and them was obvious reflecting the rivalry between the two groups. Before Grup Munzur, the music group affiliated with the DHF, took the stage, one of my respondents urged me, "Pay attention now, here comes our guys". Then a group of DHF supporters, composed of several hundreds, marched in the stadium chanting their slogan "Our leader is Ibrahim, Ibrahim Kaypakkaya". It was openly a tour de force expressing their influence and claims over Dersimli politics against the other political groups, in particular the Kurdish movement. In this vein, political groups would use the stadium events for showcasing their power by assembling their supporters and displaying their symbols.

Not all the musicians taking stage in the Munzur Festival were party-affiliated. Musicians like Metin Kahraman and Mikail Aslan, who sing in Kirmancki for the most part and happen to be important figures of contemporary Dersimli music, are remarkably appealing to the younger generation of Dersimlis. They would attract a broad crowd during the concerts. Their music is as a way of connecting with Dersimli past and expressing collective identity for younger generations (Neyzi, 2002). These musicians are also as popular among the Kurdish and left-wing circles in Turkey. Their music does not convey explicit political messages, rather re-interprets the traditional Dersimli music and oral poetry in modernized forms.

The recreational sociabilities that took place out of the festival program were also significant habitats that reinforce cultural and political belongings, and the sense of community. Hundreds of young people, both local and diasporic Dersimlis and other visitors, preferred staying in camp sites at the shores of the Munzur and Pulumur rivers during the festival time. Many would spend their time collectively at the campsites. At nights, sitting by the camp fires, they would socialize, engage in romantic-sexual encounters, and entertain themselves. Consumption of alcohol was prevalent. Performing popular protest songs and Kurdish music, tunes about the struggle of the Kurdish and revolutionary socialist movements was a popular recreational activity at the campsites that would generate entertainment and solidarity while affirming political belongings. The informal and relaxed sociabilities at the camp sites during the evening and night time contrasted with the serious political tone of the panels which were held during the day time, in open air under the fiery summer weather of Dersim.

I encountered once and heard several times about altercations erupting at camp sites or the city center during the festival time. Some of these scuffles would occur between Dersimli and visitor groups coming from adjacent provinces, mainly the non-Alevi Kurdish youth. These confrontations and the ways in which they were interpreted by the Dersimli folk disclosed identity-based anxieties and the urge for selfprotection among Dersimli people. The non-Alevi Kurdish visitors, which generally referred to young men in the perception of dissident Dersimlis, were seen as a threatening force eroding the Alevi-dominant socio-

\footnotetext{
${ }^{19}$ Ibrahim Kaypakayya was the founder of the TKP/ML who died in 1973 as a result of the torture he suffered at the hands of military forces after his capture in Vartinik, a village of Dersim. In addition to being the one of the most famous socialist youth leaders of the 1968 generation in Turkey, he is one of the most-venerated political figures in Dersimli society while becoming a symbol of collective identity. Both the descendants of the TKP/ML and the Kurdish movement in Dersim frequently refer to Ibrahim Kaypakkaya in their political campaigns. The family roots of Kaypakkaya, who was an Alevi from a middle Anatolian province, is traced back to Dersim by some Dersimli commentators which contributes to his endorsement by the Dersimli people as one of their own and an intimate figure of their cultural universe.
} 
cultural environment of Dersim. They were accused of harassing women, picking fights, and imposing their political and cultural ways, such as their taste for Kurdish music.

The socio-cultural codes in Dersim are much permissive compared to a majority of cities in Turkey, especially the overtly conservative neighboring cities. To be more specific, the participation of women in social life is far more relaxed and gender segregation is relatively limited. The societally-imposed modesty codes, in terms of what is appropriate for women to wear for instance, are much less restrictive. There are several alcohol-serving restaurants in the city and it is not reprimanded that unmarried men and women go out together and spend time in these places. It is not a rare conviction among the local Dersimlis that the non-Alevi Kurdish festival visitors, mainly men, coming from a conservative background abused the liberal environment and behaved inappropriately.

While the festival accentuated the anxiety of Dersimli people about conserving cultural homogeneity and disclosed their boundaries with non-Alevi Kurds, the festive sociabilities also brought into view the intra-group differentiations. As the collective spirit generated by the Munzur Festival had eroded since the late 2000s, the asymmetries and tension between Dersimlis on the lines of spatial, class, and political differences became more visible, especially between local and diasporic Dersimlis. In this respect, local Dersimlis criticized diasporic Dersimlis for visiting their hometown only once a year for the summer holiday and not actually being a part of it anymore, yet still claiming the right to define Dersimli community's proper identity and concerns. In return, diasporic Dersimlis complained about alienation and the abrasion of congeniality on the basis of anecdotes such as the shopkeepers in Dersim scheming and trying to overcharge them during the festival time.

Going back to recreational festive sociabilities, they were met with adverse views in Dersimli society tied to political and cultural concerns. The supposedly excessive consumption of alcohol, licentious behaviors, pollution, commercialization, and estrangement were the main topics of complaint. These issues are generally interpreted as yozlaşma [corruption] within the discourse of Dersimli people, referring to the perceived socio-cultural degeneration. The following quote from an opinion piece published in the summer of 2014 in one of the online newspapers supporting Dersimli identity politics, exemplifies those commentaries:

The festival is far from engaging with the language and culture of Dersim that is becoming politicized and estranged. This is the proof that, seemingly, there won't be much participation. The festival program has fully morphed into entertainment and is incapable of conveying social and cultural messages, which will definetly be a turning point. This is where the critique and reaction of the Dersimli folk begin. The display of drug use, alcohol consumption, harassment, and other inappropriate behavior unfolds the current situation of the festival ${ }^{20}$.

Dersimli identity politics indulge in idealization of traditional socio-cultural order while framing it as egalitarian, communalist, ecological, and democratic (Sözen, 2016, p. 561).This idealization is also present in the Kurdish movement's and socialist organizations' cultural politics regarding Dersim. In this respect, the yozlaşma trope is a widely-appealed rhetoric in Dersimli public for explaining the supposedly unpleasant social transformations. Within the discourse of political groups, it is used to designate the perceived excessive consumption of alcohol and drugs along with the decreasing participation of Dersimli youth in political movements. Accordingly, alcohol and drugs are backhandedly promoted by the state forces in Dersim for pacifying the youth and removing their revolutionary potential.

Moreover, the yozlaşma trope refers to those festive sociabilities which the dissident Dersimli people interpret as immoral and disgraceful. One of my respondents, a Dersimli man in his early forties supporting the Kurdish movement, articulated his disapproval of the casual sexual relationships during the festival time as "The relationships in the campsites can get very dirty and degenerate". This strand of critique can be related to a form ascetic morality adopted by the radical socialist groups in Turkey whereby entertainment and promiscuity are shunned upon. However, asides from politics, this is also tied to Dersimli people's cultural anxieties about not presenting a morally-questionable image to outsiders whereby Alevi identity is regarded to be deviant and prone to immorality by the conventional Sunni society. Correspondingly, the degeneration discourse might be considered as a self-protective response by Dersimli people to mediate their fear of being stigmatized and as a reaction by the socialist groups for making sense of their decreasing support among younger generations.

\section{Conclusion}

Dersim represents "a mythic place of desire" (Brah, 1996, p. 192), a point of reference for the collective imagination and identification of a diasporized ethnic group. The cultural politics regarding Dersim are imprinted by the overlapping but conflicting politico-cultural planes of Dersimli public, the Kurdish movement, and the socialist left. Dersim has been constructed through a series of cultural narratives

\footnotetext{
${ }^{20}$ Gedik, H. "Festival Fiyaskosu”, Özgür Dersim, 30 July 2014. Accessed in 05 May 2019, http://www.ozgurdersim.com/haber/festival-fiyaskosu-8192.htm. Translation is mine.
} 
and performances as "sacred lands" bearing ancient wisdom, heroism, and resistance. The Munzur Festival has had a pivotal role in this construction, while it functioned as the main stage of these cultural productions and enactments providing a locale for the assembly of people and a shared focus of attention. The festival mediated the contentious activism of Dersimli people for expressing their political struggles and cultural identity, as well as articulating the agendas and cultural politics of the Kurdish movement and the socialist left.

The early period of the Munzur Festival until the mid-2000s is recalled in a positive light as the locus of Dersimli people's collective struggle against repressive politics overcoming political differences and unifying the diasporic and local Dersimlis. The festival was initiated as a group-remaking event. In time the festival transpired as an arena disclosing political competition, contestations about identity, and social fragmentation. There are two developments accounting for this transformation. First, after the Kurdish movement came to power in local government in 2004, the power balance among the political actors of Dersimli society changed. Then, as the peace negotiation process between the Kurdish movement and the Turkish government developed in the late-2000s, the political and socio-spatial demarcations became much apparent. Protests regarding the festival's organization and festive sociabilities accumulated to such an extent that in 2014 a group of local Dersimli people signed a petition addressing the Tunceli municipality for the cessation of the Munzur Festival.

The literature on public rituals and festivals point out that these collective events, along with reinforcing identities and engendering group solidarity, provide a public sphere of reflexivity (Costa, 2002). The Munzur Festival provided a vigorous public sphere of reflexivity with reference to the socio-political commentary surrounding the event. This is a consequence of the composition of Dersimli political field in which different actors, agendas, and identity claims compete, and cannot completely dominate one another. The Dersimli public is highly vocal in expressing their discontent and criticisms. Although the Kurdish movement seemed to be in charge until the end of the peace process in the festival's organization as well as in local politics, it failed to become the hegemonic actor. The other two parties functioning in Dersimli politics, competing and coalescing with each other and the Kurdish movement, emphatically articulated their opposition and provided the balancing force. These are the Dersimli identity movement advancing the ethno-cultural and religious belongings that differ from the Kurdish identity, and the socialist left promoting anti-capitalism and a vernacularized political identity.

In the summer of 2015, the peace process stumbled after the general elections, leading to vindictive state policies towards the Kurdish movement. After the failed coup attempt in 2016, political repression against pro-Kurdish actors and other critics of the government heightened dramatically. The festival in 2015 was cancelled by its organizers as a gesture of mourning after a terrorist attack by ISIS in an eastern province killing thirty three young people affiliated with a socialist group. Correspondingly, there were frightening rumors taking a hold in Dersimli public that the ISIS would carry out another attack during the festival time. In 2016, the Munzur Festival took place in a politically tense environment whereby military operations and security controls once again intensified. Compared to earlier years, the festival was tarnished whereby the number of visitors, especially the diasporic Dersimlis from Europe was much lower as they were intimidated to visit their hometown. Moreover, state controls and restrictions over the festival activities were increased such as the prevention of a ceremonial visit to a jiyara while the road had been shut down for security reasons and the intervention to the public screening of a documentary narrating the life of a distinguished PKK militant.

In the autumn of 2016, the Tunceli municipality was deposed by statuary decree as part of the postcoup attempt anti-terrorism measures of the government. The governor was assigned as the head of municipality. In 2017 and 2018, the municipality now being run by the government, did not organize the festival. The DEDEF together with the Kurdish party and other left-wing political groups in the city applied for permission from the governorate to organize the festival, yet they were rejected on the grounds that the event contributes to terrorist propaganda.

Time will tell in what form the Munzur Festival continues in the following years and whether it rises as a group-making public celebration once again uniting the political and socio-spatial divergences in Dersimli society as the repressive state policies intensifies in the country. One thing is for sure that the Munzur Festival, despite all the contestation and criticisms and maybe owing to them to an extent, proved to renew the political and cultural energies of Dersimli, Kurdish, and socialist publics in Turkey. Mass rallies, concerts, public and private discussions, and socializing in a relaxed environment generated an energized vibrant social life during the festival time. The collective performances, sociabilities, and symbolisms which the Munzur Festival set in motion reinforced ethno-political belongings. They also sustained the senses of solidarity and mutual trust which are much needed for the left-wing public opposition and subaltern groups in contemporary Turkey.

\section{References}

Akçınar, M., \& Zırh, B. C. (2013). Derin bir kuyu Dersim'e Berlin'den bakmak. In Ş. Aslan, S. Aydın and Z. Hepkon (Eds.), Dersim 'i Parantez'den Çıkarmak (pp. 43-75). İstanbul: İletişim. 
Akkaya, A. H., \& Jongerden, J. (2011). The PKK in the 2000s: Continuity through breaks. In M. Casier \& J. Jongerden (Eds.), Nationalisms and Politics in Turkey: Political Islam, Kemalism and the Kurdish Issue (pp. 143-162). London: Routledge.

Ayata, B. \& Hakyemez, S. (2013). The AKP's engagement with Turkey's past crimes: An analysis of PM Erdoğan's "Dersim apology”. Dialectical Anthropology, 37, 131-143.

Brah, A. (1996). Cartographies of Diaspora: Contesting Identities. London: Routledge.

Bruinessen, M. v. (1997). Aslını inkar eden haramzadedir: The debate on the ethnic identity of the Kurdish Alevis. In K. Kehl-Bodrogi, B. Kellner-Heinkele \& A. Otter-Beaujean (Eds.), Syncretistic Religious Communities in the Near East (pp. 1-23). Leiden: Brill.

Bruinessen, M. v. (1994). Genocide in Kurdistan? The suppression of the Dersim Rebellion in Turkey (1937-38) and the chemical war against the Iraqi Kurds (1988). In G. J. Andreopoulos (Ed.) Genocide: Conceptual and Historical Dimensions (pp. 141-170). Philadelphia: University of Pennsylvania Press.

Cavanaugh, K. \& Hughes, E. (2015). A democratic opening? The AKP and the Kurdish Left. Muslim World Journal of Human Rights, 12, 53-74.

Collins, R. (2001). Social movements and the focus of emotional attention. In J. Goodwin, J. M. Jasper, \& F. Polletta (Eds.), Passionate Politics: Emotions and Social Movements (pp. 27-44). Chicago: University of Chicago Press.

Conquergood, D. (1991). Rethinking ethnography: Towards a critical cultural politics. Communication Monographs, 58, 179-194. doi:10.1080/03637759109376222

Costa, X. (2002). Festive traditions in modernity: The public sphere of the festival of the 'Fallas' in Valencia (Spain), The Sociological Review, 50, 482-504.

Dinç, P. (2018). Novels and short stories as products of nationalist competition: the case of Dersim 19371938 in Turkish politics and literature. Nationalities Papers, 46, 144-157. doi:10.1080/00905992.2017.1350153

Faltis, C. (2014). Toward a Race Radical Vision of Bilingual Education for Kurdish Users in Turkey: A Commentary. Journal of Ethnic and Cultural Studies, 1(1), 1-5.

Gezik, E. (2012). Alevi Kürtler. İstanbul: İletişim.

Gürtaş, İ. (2015). Dersim Alevilerinde kimlik inşası ve travma. In Y. Çakmak \& İ. Gürtaş (Eds.) Kızılbaşlık Alevilik Bektaşilik: Tarih-Kimlik-Inanç-Ritüel (pp. 309-325). İstanbul: İletişim.

Hacaloğlu, A. et al. (1996). Doğu ve Güneydoğu Anadolu'da boşaltılan yerleşim birimlerine ilişkin meclis araştırma raporu. Grand National Assembly of Turkey, Retrieved from https://www.tbmm.gov.tr/sirasayi/donem20/yil01/ss532.pdf.

Leal, J. (2015). Festivals, group making, remaking and unmaking. Ethnos, 81, 584-599. doi:10.1080/00141844.2014.989870.

Leezenberg, M. (2003). Kurdish Alevis and the Kurdish nationalist movement. In P. J. White \& J. Jongerden (Eds.), Turkey's Alevi Enigma (pp.197-212). Leiden: Brill.

Neyzi, L. (2002). Embodied elders: Space and subjectivity in the music of Metin-Kemal Kahraman. Middle Eastern Studies, 38, 89-109.

Orhan, G. (2013). Ekoloji ve siyaset: Munzur baraj projelerine karşı toplumsal direniş örneği.” In Ş. Aslan, S. Aydın and Z. Hepkon (Eds.), Dersim 'i Parantez'den Çıkarmak (pp. 253-272). İstanbul: İletişim.

Somers, M. (1994). The narrative constitution of identity: A relational and network approach. Theory and Society, 23(5), 605-649.

Scalbert-Yücel, C. (2016). Common ground or battlefield? Deconstructing the politics of recognition in Turkey. Nationalism and Ethnic Politics, 22, 71-93. doi:10.1080/13537113.2016.1133862.

Sözen, Ü. (2013). Neo-Dersim kültür alanı: Siyaset ve piyasa ekseninde hafizanın ve kültürün Nesneleşmesi. In Ş. G. Tuna \& G. Orhan (Eds.), Dört Dă̆a Siğmayan Kent (pp. 249-305). Istanbul: Patika.

Sözen, Ü. (2016). Sembollerde cemaati aramak ve kimliği yeniden kurmak: Dersim'de hafiza, yerellik ve siyaset. Praksis, 42, 553-81.

Strunc, A. (2019). The Politics of Culture. Journal of Culture and Values in Education, 2(1), 71-80. Retrieved from http://cultureandvalues.org/index.php/JCV/article/view/26

Taş, C. (2007). Külden Evler: Dersim'de Yakılan Köylerin Öyküsü. İstanbul: Tij.

Tolba, N. (2018). From Rebellion to Riots. Research In Social Sciences And Technology, 3(2), 93-114. Retrieved from http://ressat.org/index.php/ressat/article/view/358

Tosun, M. (2015). Belleğin tanıklığında hakikat ve kimlik Arayışı. Praksis, 39, 131-177.

Törne, A. (2015). On the grounds where they will walk in a hundred years' time - Struggling with the heritage of violent past in post-genocidal Tunceli, European Journal of Turkish Studies, 20. Online since 01 March 2015, connection on 19 April 2019. Retrieved from http://journals.openedition.org/ejts/5099

Turner, V. (1988). The Anthropology of Performance. New York: PAJ Publications. 
Sözen, Ü.

Yildirim, M. (2013). Dersim'in Cumhuriyet öncesindeki sosyo-ekonomik yapısı üzerine bir inceleme. In Ş. G. Tuna \& G. Orhan (Eds.), Dört Dağa Slğmayan Kent (pp. 41-70). Istanbul: Patika. 